\title{
Becoming a Pre-School and Elementary School Educator: How do Male Teachers Describe their Career Decision and Career Development from the Perspective of the Social Cognitive Career Approach and Human Resource Management
}

\section{Luis Miguel Dos Santos}

Woosong Language Institute, Woosong University, Daejeon, South Korea Email:luismigueldossantos@yahoo.com

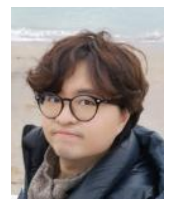

\begin{abstract}
This study investigated the sense-making process and career decision and development of male pre-school and elementary school teachers in the New England region in the United States through the perspective of Social Cognitive Career Theory (SCCT). Two research questions guided this study. First, why male teachers decided to join the pre-school and elementary school profession as their life-long career development, and second, how do male teachers describe their position and the sense-making process of their profession. Based on the Interpretative Phenomenological Analysis (IPA), the researcher invited and collected rich and in-depth data from ten participants. The results indicated that male pre-school and elementary school teachers believed their gender status and role could provide unique modelling for young children, particularly those from a single-parent family. Also, many believed that human resource professionals and school leaders should pay attention to gender diversity and gender inequality issues in the areas of the pre-school and elementary school environments. Based on the in-depth sharing, the results of this study could become a blueprint for school leaders and human resource professionals to direct their workplace and gender inequality issues toward male professionals in the current K-12 educational environment.
\end{abstract}

Keywords: Elementary school teachers, Gender inequality, Human resource management, Male teachers, Pre-school teachers, School administration, School discrimination, Social cognitive career theory, Social justice.

Citation | Luis Miguel Dos Santos (2020). Becoming a Pre-School and Elementary School Educator: How do Male Teachers Describe their Career Decision and Career Development from the Perspective their Career Decision and Career Development from the Perspective
of the Social Cognitive Career Approach and Human Resource Management. Journal of Education and e-Learning Research, 7(2): 159-166.

History:

Received: 13 March 2020

Revised: 16 April 2020

Accepted: 19 May 2020

Published: 9 June 2020

Licensed: This work is licensed under a Creative Commons

Attribution 3.0 License (cc) E E

Publisher: Asian Online Journal Publishing Group
Funding: This study received support from Woosong University Research Funding 2020

Competing Interests: The author declares that there are no conflicts of interests regarding the publication of this paper.

Transparency: The author confirms that the manuscript is an honest, accurate, and transparent account of the study was reported; that no vital features of the study have been omitted; and that any discrepancies from the study as planned have been explained.

Ethical: This study follows all ethical practices during writing.

\section{Contents}

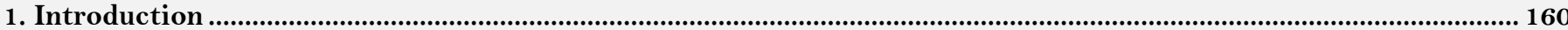

2. Methodology

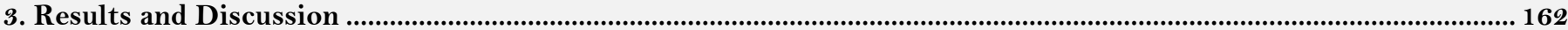

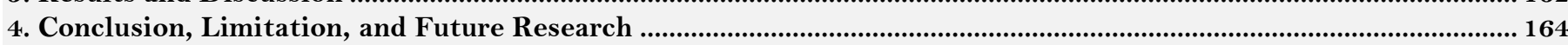

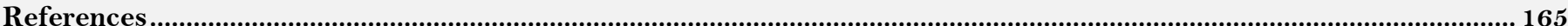




\section{Contribution of this paper to the literature}

This paper contributes to the fields of organisational leadership, school human resource management, school inequality, and social justice.

\section{Introduction}

The shortage of qualified pre-school and elementary school teachers in the United States is a serious problem across all 50 American states, Washington District Columbia, and several overseas territories. The problem is particularly prevalent in rural communities which are less attractive to both in-service and pre-service teachers (Dos Santos, 2019b; Dos Santos, 2019c; Weiner, 2012; Weiner \& Jerome, 2016). According to the United States Bureau of Labour Statistics, the potential growth of K-12 teachers is around $3-4 \%$ due to the increasing demand from the growing population (Statistics B of Labor, 2020). However, many researchers (Dos Santos, 2016; Skaalvik \& Skaalvik, 2017) indicate that teachers are more likely to leave their teaching position and even quit the teaching profession every year due to stress, workload, financial considerations, and responsibilities (Weiner \& Jerome, 2016). Due to the unbalanced student-teacher ratio, the teacher human resources shortage continues to be the main issue for school human resource management.

For nearly half a century, human resource professionals, policymakers, and school leaders have encouraged both secondary school graduates and career changers to enter the teaching profession (Chambers, 2002). However, pre-school and elementary school education does not seem to be a potential, attractive career development for male teachers wanting to provide educational services to young children. Due to social, cultural, and gender biases in the field of pre-school and elementary school education, the public members usually consider pre-school and elementary school systems to have a female bias due to the nursery and caring orientation. Although gender and social roles should be taught at an early age, the social and gender biases always limit the enrolment and participation of potential male pre-school and elementary school teachers from joining the profession (Yu, Wang, Zhai, Dai, \& Yang, 2015). Many parents, school leaders, policymakers, and educational researchers advocated the desires of male pre-school and elementary school teachers. The encouragements did not increase the overall enrolments of male students into the programme and profession (Erden, Ozgun, \& Ciftci, 2011).

Pre-school and elementary school teachers play significant roles in helping early age children's performance, physical development, and cognitive growth (Erden et al., 2011). Students could learn different skills and abilities from male and female teachers as their conducts, teaching and learning strategies, mental stages, and social roles were not the same. In other words, the knowledge bases and thought processes of both male and female teachers were different (Hansen \& Mulholland, 2005; Marks, 2000). Although gender bias is not a limitation for career selection in the United States and other westernised countries and regions, most male individuals do not choose pre-school and elementary school teaching as their life-long career decision and career development.

Research indicated that for children from single-parent families, particularly children from single-mother families, young children's growth can be beneficial due to the social and gender roles of male pre-school and elementary school teachers (Cameron, 2001). A single-parent family is a common family structure due to social and cultural development over the decades. A large number of children are raised in a single-mother family where the father's social and gender role was absent. Therefore, without the understanding of how male individuals work in a family, many boys do not understand the conducts of their male models. Sevier and Ashcraft (2009) indicated that the teaching and educational services of male pre-school teachers were not their major concerns. Rather, male preschool teachers provided the social and gender roles and models which female teachers could not do(Sevier \& Ashcraft, 2009).

Gender inequality (Robinson, McGee, Bentley, Houston, \& Botchway, 2016; Yeung, 2011) is another concern in the current educational profession. Many advocated that career development should not be limited due to gender. For nearly a century, a large number of NGOs, government agencies, educational institutions, religious organisations, and public members have been advocating the working rights of female individuals in the workplace. However, men's rights in the pre-school profession were not actively addressed. Currently, many (Shek \& Wu, 2014) suggest that government agencies, business leaders, top-level boards, Congress, and Parliament should encourage more female individuals for gender diversity. However, no one has made a parallel suggestion for reforms and improvements in the current pre-school environments.

Further discouragements for individuals joining the pre-school profession were the excessive responsibilities, long working hours, social caring commitment, poor starting salary, and potential career development, particularly for men who may need to take care of their family (Betoret \& Artiga, 2010; Yang, Fan, Chen, Hsu, \& Chien, 2018). For the above reasons, after the completion of student-teaching placements and internships, many pre-service, preschool and elementary school teachers will not join the profession. Also, in-service and pre-school teachers left the teaching profession for various reasons (Dos Santos, 2019d; Glutsch \& König, 2019; Im, Yoon, \& Cha, 2016). For a large number of reasons, the pre-school and elementary school profession is one of the most challenging professions in which to recruit potential teachers, particularly male individuals.

\subsection{Purpose of the Study}

For nearly half of a century, school human resource management and teacher shortages have been a serious problem (Hardman, 2001; Ingersoll, 2001; Weiner \& Jerome, 2016). Based on this background, the current study aims to understand the career decision and career development of ten male pre-school and elementary school teachers who have been working in the profession for at least ten years in the New England region in the United States. Three significant areas were captured for this study, as follows.

First, based on the current social, cultural, and educational environment in the United States, the general public, parents, school leaders, and even students advocated that pre-school and elementary school teachers should be female individuals. Based on this information, the researcher explored the reasons why male teachers decided to join the pre-school and elementary school profession as their life-long career development.

Second, as the numbers of male pre-school and elementary school teachers are fewer than female teachers, the researcher investigated how male teachers describe their position and the sense-making process of their profession. 
Last but not least, the results of this study captured meaningful data from male pre-school and elementary school teachers. The results encouraged school leaders, human resource professionals, policymakers, government agencies, department heads, and researchers to reform and improve the current human resource planning and organisational leadership approach.

\subsection{Theoretical Framework}

The Social Cognitive Career Theory (SCCT) is a model that explores, from a career perspective, how academic interests, choices, and performance influenced peoples' career decisions (Lent \& Brown, 1996; Lent, Brown, \& Hackett, 1994). In its development, the theory merged four elements: self-efficacy beliefs from the central notion of social cognitive theory (Bandura, 1986; Bandura \& Adams, 1977), outcome expectations, interests, and goals.

The theory advocates that people's career decisions and behaviours are always influenced by both internal and external elements, which might include personal and background factors. Personal influences include gender, ethnicity, age, sexual orientation, health status, and place of origin Hackett, Betz, Casas, and Rocha-Singh (1992); Swanson and Gore (2000). Background elements include social networks, school relations, and peer interactions. Peoples' beliefs could be changed due to various internal and external factors. For example, previous studies indicated that the career decision and development of international school teachers in remote regions could be influenced by social isolation and lack of networking due to the location of the school (Dos Santos... 2019e). Another study proposed that the managerial styles of the school leaders could influence a teacher's job satisfaction and turnover decision as a network (Dos Santos, 2016). Further, it is worth noting that second-career teachers might give up their original professions as scientific researchers due to their family and financial commitments (Dos Santos, 2019a).

Therefore, peoples' behaviours could be impacted and altered for different reasons. For this study, the researcher employed the SCCT (Brown, Steven, \& Lent, 2017; Lent \& Brown, 1996; Lent et al., 1994; Lent, Lopez, Lopez, \& Sheu, 2008; Swanson \& Gore, 2000) as the lens used to explore this particular group of male pre-school and elementary school teachers and to understand their career decision and sense-making process in this femaledominated profession in the United States.

\section{Methodology}

\subsection{The Application of Interpretative Phenomenological Analysis}

The researcher employed the qualitative research method with the application of the Interpretative Phenomenological Analysis (IPA). The IPA is a useful methodology to collect rich and in-depth data concerning the inner world, sense-making process, and lived stories of the participants. Researchers (Larkin \& Thompson, 2011) advocated that the IPA has the epistemological and hermeneutic approaches (Boblin, Ireland, Kirkpatrick, \& Robertson, 2013). Researchers and studies with these focuses tend to collect data about the relationship and engagement of the peoples' social interactions together with their inner world. Three key elements have been summarised (Larkin \& Thompson, 2011):

- First, peoples' inner world and understanding always related to their personal experiences and background (Tang \& Dos Santos, 2017). For example, an earlier study (Dos Santos, 2016) indicated that peoples' career perspectives and decisions could be influenced by their social and external environments and behaviours. As a result, without people's background and experience, researchers could not seek the performance and understanding of their inner world.

- Second, the IPA always seeks to understand individuals' social and inner worlds from exploring their conversational, oral, cultural, social, environmental, mental, and physical backgrounds and experience (Smith \& Osborn, 2003). These approaches allow the researchers to obtain meaningful data with which to interpret the social and inner world of the individuals.

- Third, the IPA has a narrow focus on a particular situation or social phenomenon. In other words, the researchers tend to seek relationships and engagements with something specific or unique to the peoples' backgrounds and experience (Brocki \& Wearden, 2006).

\subsection{Brief Background of the Participants}

Ten in-service, male pre-school and elementary school teachers $(\mathrm{N}=10)$ with at least ten years of teaching experience were invited to participate in this study.

Table-1. Demography of the participants.

\begin{tabular}{c|c|c|l}
\hline Name & Teaching Service & Years of Experience & Highest Qualification \\
\hline Teacher \#1 & Elementary & 13 & Master's degree \\
\hline Teacher \#2 & Elementary & 20 & Master's degree \\
\hline Teacher \#3 & Pre-school & 18 & Master's degree \\
\hline Teacher \#4 & Pre-school & 14 & Master's degree \\
\hline Teacher \#5 & Pre-school & 11 & Master's degree \\
\hline Teacher \#6 & Elementary & 23 & Doctorate \\
\hline Teacher \#7 & Pre-school & 15 & Master's degree \\
\hline Teacher \#8 & Elementary & 20 & Master's degree \\
\hline Teacher \#9 & Pre-school & 21 & Master's degree \\
\hline Teacher \#10 & Elementary & 25 & Doctorate \\
\hline
\end{tabular}

All participants agreed to engage. All the participants were first-career teachers without any other professional experiences. Table 1 above outlines the demographics of the participants. 


\subsection{Data Collection}

Two sessions of semi-structured, one-on-one, private interviews were performed to collect meaningful data from the participants (Seidman, 2013). For each interview session, the researcher aimed to capture the career decision and career development of the participants, and examine how they described their role as male pre-school and elementary school teachers in female-dominated professions. In short, each interview session had separate themes of interview questions. The first interview session addressed why male teachers decided to join the preschool and elementary school profession as their life-long career development. The second interview session related to how male teachers describe their position and the sense-making process of their profession. Each interview hosted approximately 120 minutes per person.

\subsection{Data Analysis}

Themes, subthemes, and categories were captured and grouped together after the data collection procedure. The general inductive approach (Tang \& Dos Santos, 2017; Thomas, 2006) was employed to analyse the interview data. Due to the nature of this study and the data collection procedures (i.e. in-depth interview and lived stories sharing), a large number of conversations and sharings were collected. Therefore, the researcher needed to employ the open-coding technique to narrow down the large volume of information into the first-level (Creswell, 2014; Merriam, 2009) themes and subthemes. After the researcher categorised all the information into several sections, the researcher needed to employ the axial-coding technique (Creswell, 2014; Merriam, 2009). Subsequent to this, the second-level themes and subthemes were merged. As a result, two themes and four subthemes were categorised for reporting.

\subsection{Human Subjects Protection}

Protecting the personal information of the participants was a crucial factor of this study. Therefore, the researcher locked all the unsigned and signed agreements, personal details, audio-recordings, transcripts, computers, and related materials into a password-protected cabinet. Only the researcher had the rights to open and read the information. After the data analysis procedure, the researcher deleted and destroyed the related materials immediately due to privacy laws.

For further human subject protection, participants' workplaces (i.e. pre-school and elementary schools), ages, and names were masked. The population of male teachers in the fields of pre-school and elementary schools were limited. The researcher needed to protect all the related information to protect their social networking and job opportunities.

\section{Results and Discussion}

After 20 rounds of in-depth, one-to-one participant interviews, the researcher collected a substantial amount of meaningful data from ten in-service. male pre-school and elementary school teachers. Each participant received the same protocol and interview questions to prepare and answer. Thus, the semi-structured interviews outlined the directions which the researcher tended to respond to the research questions and purposes of this study. Based on the data and with the guideline of the SCCT (Brown et al., 2017; Lent \& Brown, 1996; Lent et al., 1994; Lent et al., 2008; Swanson \& Gore, 2000) the researcher categorised two themes and four subthemes, outlined in Table 2.

Table-2. Themes and subthemes.

\begin{tabular}{|c|c|}
\hline \multicolumn{2}{|c|}{ Themes and Subthemes } \\
\hline 1. Est & shing the male modelling at pre-school and elementary school environments \\
\hline 1.1 & Providing social status as male individuals \\
\hline 1.2 & Teaching the curriculum and instruction beyond the females' perspective \\
\hline \multicolumn{2}{|c|}{ 2. Increasing the diversity in the female-dominated working environment } \\
\hline 2.1 & $\begin{array}{l}\text { External: Educating parents about the advantages of male pre-school and elementary school } \\
\text { teachers }\end{array}$ \\
\hline 2.2 & Internal: Balancing the gender diversity in the workplace \\
\hline
\end{tabular}

\subsection{Establishing Male Modelling in Pre-School and Elementary School Environments}

Some earlier studies (Cushman, 2010; Erden et al., 2011; John Martino, 2008; Martino \& Kehler, 2006) indicated that pre-school and elementary school students would reap benefits from having male teachers as their models. In particular, many children from single-parent families (usually single-mother) do not have the social and cultural role-models of a father figure. As children spent most of their time at school, male teachers served as their social, cultural, and gender models (Martino \& Kehler, 2006). Although father, uncles, and brothers might be their models during leisure and family times, teachers are always their closest models outside their family zones. The following sections outline the in-depth sharing of how male modelling as teachers at pre-school and elementary schools could influence overall performance, development, and growth from the perspective of male teachers. More importantly, how these beliefs and perspectives influenced their career decisions and career development (Dos Santos, 2019b; Dos Santos, 2018) as male pre-school and elementary school teachers in a female-dominated profession.

\subsubsection{Providing Social and Gender Status and Role as Male Individuals}

Traditionally, the father in the family serves as the financial provider while the mother serves as the housewife. However, such traditional family structures were absent in some of the single-parent families, regardless of whether single-mother or single-father families. Although there are no rules to say how boys and girls should work and act in society and communities, it is expected that boys should establish masculinity (Martino \& Kehler, 2006). However, masculinity and related behaviours could not be learned and transferred by female pre-school and elementary school teachers. Therefore, all ten participants expressed the concerns about and interests in transferring the male status and roles to their young students during their early age. One said: 
Although children usually do not have a sense of gender, we have to tell them that boys and girls are not the same...based on the ideas of Sigmund Freud, pre-school female students could experience penis envy due to body condition and differences. So, male teachers and female teachers should use their social and gender roles for this instruction. It is hard for a female to provide males' social and gender status and role education, as they are not male...(Teacher \#4, Pre-School)

Some participants opined that teaching and learning tools and materials are not the same for boys and girls. For example, a teacher indicated that the pattern of play and games showed the differences between the two genders, such as cars and dolls. They said:

From my knowledge of early childhood education and my placement at the school, my professors and supervisors told us that we needed to expect some toys between two genders. But how to play with the toys and play appropriately...we need those appropriate teachers to teach that... so female teachers understood the tools of the gendered toys with the theories, but they don't understand how to play the toys appropriately (Teacher 9, Pre-School)

In short, from the perspectives of the SCCT, organisational psychology, and human resource management, participants advocated that their unique gendered status and roles are vital to their serving students and the school environment. Many (Halimi, Consuegra, Struyven, \& Engels, 2016) opined that their skills and abilities are beneficial to their students as many students could gain a sense of gender, physical condition, and mental differences from both female and male teachers in the school environment. Although many pre-school and elementary schools in the United States may not pay attention to gender issues and human resource management, the participants suggested that gendered diversity always increased the overall performance and growth of the student population (Ehrtmann \& Wolter, 2018).

\subsubsection{Teaching the Curriculum and Instruction beyond the Female Perspective}

Schools are where students receive appropriate instructions and training from their teachers. Unlike adult education and training, pre-school and elementary school students also learn gender-oriented status and roles from peer-to-peer interactions and the modelling from their teachers (Muschkin, Ladd, Dodge, \& Bai, 2020). For this category, most expressed concerns about physical education and training for their pre-school and elementary school students, particularly most expressed that their female co-workers could not provide some unique training to students. One said:

...especially for physical education...female teachers could not teach some special techniques from male teachers' perspectives, vice versa. I am not saying female teachers are not good. But the differences and ways of teaching between two genders are not the same (Teacher \#1, Elementary School)

The researcher also captured another expression of physical education training from male teachers (EscrivaBoulley, Tessier, Ntoumanis, \& Sarrazin, 2018). This participant believed that if gender is the same, then sports teams would not distinguish men and women's team. Also, both physical appearance and body conditions of boys and girls are different. It is important for children to receive knowledge and training from different teachers. One said:

...boys' physical training should focus on energy and muscle training while girls should focus on techniques which boys may miss... one teacher cannot do all the things. That's why we need different teachers for different subjects... in elementary school, this is also important, no teachers can cover all courses (Teacher \#10, Elementary School)

From a different perspective, many participants also advocated that some subject matters and fields might not be their expertise due to preferences and gender differences (Escriva-Boulley et al., 2018). For example, many advocated that they could not handle foreign language courses. Based on the guidelines of the SCCT and the concepts of human resource management, school leaders and administrators should allocate the appropriate personnel to suitable positions. At the same time, employees and workers should also suggest the leaders for such human resource arrangements. One, while sharing the human resource management for their teaching subject matters, said:

Elementary school teachers should teach from the generalist perspectives, it means...teachers should handle most of the subjects... but some subjects, such as foreign language, some teachers or female teachers may have the better abilities due to the gender differences... some male teachers, may have better logical skills... I am not saying female teachers can't do. But from the human resource perspective, this is the appropriate human resource management...(Teacher \#6, Elementary School)

In short, all participants advocated that their modelling and presence encouraged their students' overall performance, physical condition, and mental development due to gendered-oriented roles and status. Many parents and members of the public might have different levels of misunderstanding about their roles due to social and cultural biases and stigma. However, from the perspective of the SCCT, organisational psychology, and human resource management, all participants overcame the social and cultural biases and stigma as they believed the missions and educational services encouraged their career development in this female-dominated profession. More importantly, these themes and subthemes captured why male pre-school and elementary school teachers decided to stay in this field due to their understanding of male teachers' roles and status in their school and classroom environments.

\subsection{Increasing Diversity in the Female-Dominated Working Environment}

Previous studies (Dekhtyar, Weber, Helgertz, \& Herlitz, 2018) indicated that social, cultural, and gender elements occupied some preferences and directions of industries and professions. For example, in the fields of preschool and elementary school systems, members of the general public tended to advocate that female teachers and leaders are the appropriate personnel for the role (Erden et al., 2011). Such gender biases were also found in the fields of nursing and the culinary arts (Cottingham, 2019). Studies also found that male nursing teachers, students, and in-service professionals faced many challenges and difficulties due to their gender with social biases and stigma. Many males do not have any plans to enter these female-dominated industries and professions due to the biased conceptions from the members of the public (Herd et al., 2019). As a result, such industries and professions have difficulties in recruiting enough male personnel for the large gaps in human resource management. The following two subthemes categorised the contemporary issues in the areas of pre-school and elementary school 
systems, particularly the difficulties of male teachers' recruitment and retention due to social, cultural, and gender biases. From the guidelines and perspectives of the SCCT, the researcher tended to capture how these biases influenced the career decision and career development of male teachers in pre-school and elementary school environments. More importantly, the researcher tended to explore how these male teachers explained potential solutions and suggestions for this human resource issue.

\subsubsection{External: Educating Parents about the Advantages of Male Pre-School and Elementary School Teachers}

All participants expressed that their co-workers, school leaders, government agencies, and policymakers understood the unique status and role of pre-school and elementary school teachers in the current educational system (Erden et al., 2011). However, most members of the public and parents did not understand their positions in pre-school and elementary schools regarding social biases and stigma. All experienced negative feedback and opinions from parents (Pangrazi \& Beighle, 2020). For example, some parents asked the school leaders and administrators to transfer their children to other female teachers' classrooms due to the gender of the male participants. As male teachers in the current school systems are beneficial to students, school leaders and administrators needed to handle this human resource management wisely and appropriately to avoid any workplace bullying or gender-oriented discrimination toward male teachers. For such male teachers' conflicts and social biases, some male teachers shared how their school leaders and administrators handled this social, cultural, and gender bias. One said:

My school hosted parents day every quarter... so male teachers are always encouraged to be the school representatives. My school and our school district needed to tell people we are the discrimination-free system. We have to educate parents that both male and female teachers have equal abilities and skills for teaching...(Teacher \#7, Pre-School)

\subsubsection{Internal: Balancing Gender Diversity in the Workplace}

Besides the external promotion and education for parents, students, and public members in communities, most of the school took additional steps toward workplace diversity and effective human resource management and strategies. From the teachers' perspective, they believed that their positions and teaching services always increased gender diversity and rich teaching and learning environments on campus (Muschkin et al., 2020). Most of them shared that their position and male modelling always encouraged their students to understand that both female and male individuals and professionals have equal social, cultural, and gender status and roles in society (John Martino, 2008). One said:

... in the open society, people can do any jobs based on their purposes and interests...pre-school and elementary school must

follow the same way. But people always think that early childhood education is reserved for female teachers, which is not true. The roles of all of us here... are to increase the gender diversity and rates between female and male teachers...I don't care about the discrimination or social bias, I am here for my students...(Teacher \#5, Pre-School)

Another participant advocated that his teaching service could reform how members of the public viewed the pre-school and elementary school system (Herd et al., 2019). Many members of the public believed male teachers should not provide instructions to young children due to their gender. However, such social biases and stigmas were not supportive and not true all the time. One participant expressed his concern and interest about the existence of male teachers and professionals on campus, saying;

... as a male teacher, I am not here for my own good, I am there to do some good thing for the next generation. The educational system cannot continue without any male workers and teachers. This is why male teachers are important... also, gender diversity is vital in the system as well. The gender discrimination, or problem, is very serious in the pre-school and elementary system... we have to do something to change it...(Teacher \#3, Pre-School)

Additional support for male professionals at pre-school and elementary schools is to recruit additional male school professional staff. For example, many participants indicated that their schools always recruit male counsellors, administrative staff, social workers, and librarians to increase the gender diversity on campus. One said:

There are no ways for our school district to recruit because there are no potential male teachers in the market. So our school actively recruited librarians, counsellors, and social workers to meet or increase the gender diversity...of course, the recruitment wasn't just for gender diversity... those school professional staff must be qualified and appropriate...not just because they needed to be hired because the school needed them...(Teacher \#8, Elementary)

In short, from the perspectives of the SCCT and human resource management, most participants decided to stay in the pre-school and elementary school profession due to their external and internal contributions to the field. First, beyond being role models for their students, all advocated that there is a need to support the gender inequality (John Martino, 2008; Skelton, 2003) in the current educational system, particularly male teachers in the pre-school and elementary school classroom environment. Besides teaching the students (i.e. next generation), they used their statuses and roles as teaching materials. As a previous study (Cushman, 2010) indicated, male teachers always take important roles as the positive images of the pre-school and elementary school environment. Second, due to social and cultural biases and stigmas, many potential male teachers decided not to join the pre-school and elementary school environment. Most advocated that, without a doubt, their contribution benefitted not only their students, but also the school environment, particularly in the areas of gender diversity.

\section{Conclusion, Limitation, and Future Research}

The results of this study provided an overview and holistic picture of the human resource situation, and career decision and career development, of male pre-school and elementary school teachers in the United States. Although the results may only reflect the situation in the United States, many countries, regions, and cities with a similar background may use the results to reform and improve their current human resource management at the school environment. Male teachers' population is very important for the current K-12 educational system, particularly in the areas of gender diversity and students' physical condition, overall performance, and mental development. School leaders, administrators, human resource professionals, government agencies, policymakers, and researchers 
should take this result as a blueprint to polish and reform their school management and current educational policy to attract additional potential male teachers in pre-school and elementary school environments.

\subsection{Limitations and Future Research}

Every study has its limitations, and the current study had two. First, the researcher collected the data from the New England region in the United States. The United States is one of the largest countries in the world. The results of the study could only reflect the situation in the New England region. Male pre-school and elementary school teachers in other, different parts of the United States might have different feedback, sharing, and understanding due to diverse geographic and population backgrounds. Therefore, future researchers might expand the scopes and aim the study at different populations in the United States to collect the holistic picture for the whole country.

Second, the current study could only question ten participants due to the limited population in the study area. Therefore, the researcher needed to employ the IPA to reduce the biases from the data. The current study employed in-depth interview tools to collect rich and meaningful information for further confirmation of the results. However, if the study could expand to a larger demographic, the results could be more informed due to wider sharing. Therefore, future researchers might expand the participants' population. Nevertheless, the current in-depth and rich results always improved the current literature gaps about the human resource and school recruitment issues of male pre-school and elementary school teachers.. Interested readers should reform their school systems to compete in a rapidly changing environment.

\section{References}

Bandura, A. (1986). Social foundations of thought and action: A social cognitive theory. Englewood Cliffs, NJ: Prentice-Hall.

Bandura, A., \& Adams, N. E. (1977). Analysis of self-efficacy theory of behavioral change. Cognitive Therapy and Research, 1(4), 287-310. Available at: https://doi.org/10.1007/bfo1663995.

Betoret, F., \& Artiga, A. (2010). Barriers perceived by teachers at work, coping strategies, self-efficacy and burnout. The Spanish Journal of Psychology, 13(2), 637-654. Available at: https://doi.org/10.1017/S1138741600002316.

Boblin, S. L., Ireland, S., Kirkpatrick, H., \& Robertson, K. (2013). Using stake's qualitative case study approach to explore implementation of evidence-based practice. Qualitative Health Research, 23(9), 1267-1275. Available at: https://doi.org/10.1177/1049732313502128.

Brocki, J. M., \& Wearden, A. J. (2006). A critical evaluation of the use of interpretative phenomenological analysis (IPA) in health psychology. Psychology \& Health, 87-108(1), 87-108. Available at: https://doi.org/10.1080/14768320500230185.

Brown, Steven, D., \& Lent, R. W. (2017). Social cognitive career theory in a diverse world. Journal of Career Assessment, 25(1), 173-180. Available at: https://doi.org/10.1177/1069072716660061.

Cameron, C. (2001). Promise or problem? A review of the literature on men working in early childhood services. Gender, Work $\mathscr{E}^{\circ}$ Organization 8(4), 430-453. Available at: https://doi.org/10.1111/1468-0432.00140.

Chambers, D. (2002). The real world and the classroom: Second-career teachers. The Clearing House: A Journal of Educational Strategies, Issues and Ideas, 75(4), 212-217. Available at: https://doi.org/10.1080/00098650209604935.

Cottingham, M. D. (2019). The missing and needed male nurse: Discursive hybridisation in professional nursing texts. Gender, Work $\mathcal{E}^{\circ}$ Organisation, 26(2), 197-213. Available at: https://doi.org/10.1111/gwao.12333.

Creswell, J. (2014). Research design: Qualitative, quantitative, and mixed methods appraoches (4th ed.). Thousand Oaks, CA: Sage.

Cushman, P. (2010). Male primary school teachers: Helping or hindering a move to gender equity? Teaching and Teacher Education, 26(5), 1211-1218. Available at: https://doi.org/10.1016/j.tate.2010.01.002.

Dekhtyar, S., Weber, D., Helgertz, J., \& Herlitz, A. (2018). Sex differences in academic strengths contribute to gender segregation in education and occupation: A longitudinal examination of 167,776 individuals. Intelligence, 67(March-April), 84-92. Available at: https://doi.org/10.1016/j.intell.2017.11.007.

Dos Santos, L. M. (2016). Relationship between turnover rate and job satisfaction of foreign language teachers in Macau. Journal of Educational and Developmental Psychology, 6(2), 125-134. Available at: https://doi.org/10.5539/jedp.v6n2p125.

Dos Santos, L. M. (2019a). Engineering education as a second career: The experience of female practising engineers. Global Journal of Engineering Education, 21(3), 202-207.

Dos Santos, L. M. (2019b). Investigating employment and career decision of health sciences teachers in the rural school districts and communities: A social cognitive career approach. International Journal of Education and Practice, 7(3), 294-309.

Dos Santos, L. M. (2019c). Mid-life career changing to teaching profession: A study of secondary school teachers in a rural community. Journal of Education for Teaching, 45(2), 225-227. Available at: https://doi.org/10.1080/02607476.2018.1548168.

Dos Santos, L. M. (2019d). Pre-service teachers' professional development through four-step problem-solving model: A seminar method. International Journal of Education and Practice, 7(2), 146-157. Available at: https://doi.org/10.18488/journal.61.2019.73.146.157

Dos Santos, L. M. (2018). Career decision of recent first-generation postsecondary graduates at a metropolitan region in Canada: A social cognitive career theory approach. Alberta Journal of Educational Research, 64(2), 141-153.

Dos Santos, L. M. (2019e). Recruitment and retention of international school teachers in remote archipelagic countries: The fiji experience. Education Sciences, 9(2), 1-16. Available at: https://doi.org/10.3390/educsci9020132.

Ehrtmann, L., \& Wolter, I. (2018). The impact of students' gender-role orientation on competence development in mathematics and reading in secondary school. Learning and Individual Differences, 61(1), 256-264. Available at: https://doi.org/10.1016/j.lindif.2018.01.004.

Erden, S., Ozgun, O., \& Ciftci, M. A. (2011). I am a man, but i am a pre-school education teacher: Self- and social-perception of male preschool teachers. Procedia - Social and Behavioral Sciences, 15, 3199-3204.

Escriva-Boulley, G., Tessier, D., Ntoumanis, N., \& Sarrazin, P. (2018). Need-supportive professional development in elementary school physical education: Effects of a cluster-randomised control trial on teachers' motivating style and student physical activity. Sport, Exercise, and Performance Psychology(2), 218-234. Available at: https://doi.org/10.1037/spyoooo 119.

Glutsch, N., \& König, J. (2019). Pre-service teachers' motivations for choosing teaching as a career: Does subject interest matter? Journal of Education for Teaching, 45(5), 494-5 10. Available at: https://doi.org/10.1080/02607476.2019.1674560.

Hackett, G., Betz, N., Casas, J., \& Rocha-Singh, I. (1992). Gender, ethnicity, and social cognitive factors predicting the academic achievement of students in engineering. Journal of Counseling Psychology, 39(4), 527-538. Available at: https://doi.org/10.1037/00220167.39.4.527.

Halimi, M., Consuegra, E., Struyven, K., \& Engels, N. (2016). The relationship between youngsters' gender role attitudes and individual, home, and school characteristics. SAGE Open, 6(3), 215824401665623. Available at: https://doi.org/10.1 177/2158244016656230.

Hansen, P., \& Mulholland, J. A. (2005). Caring and elementary teaching. Journal of Teacher Education, 56(2), 119-131. Available at: https://doi.org/10.1177/0022487104273761.

Hardman, J. (2001). Improving recruitment and retention of quality overseas teachers. In S. Blandford \& M. Shaw (Eds.), Managing International Schools. London, UK: Routledge Falmer.

Herd, P., Freese, J., Sicinski, K., Domingue, B. W., Mullan Harris, K., Wei, C., \& Hauser, R. M. (2019). Genes, gender inequality, and educational attainment. American Sociological Review, 84(6), 1069-1098. Available at: https://doi.org/10.1 177/0003122419886550.

Im, S., Yoon, H.-G., \& Cha, J. (2016). Pre-service science teacher education system in South Korea: Prospects and challenges. EURASIA Journal of Mathematics, Science and Technology Education, 12(7), 1863-1880. Available at: https://doi.org/10.12973/eurasia.2016.1533a. 
Ingersoll, R. M. (2001). Teacher turnover and teacher shortages: An organisational analysis. American Educational Research Journal, 38(3), 499-534. Available at: https://doi.org/10.3102/00028312038003499.

John Martino, W. (2008). Male teachers as role models: Addressing issues of masculinity, pedagogy and the re-masculinisation of schooling. Curriculum Inquiry, 38(2), 189-223. Available at: https://doi.org/10.1111/j.1467-873X.2007.00405.x.

Larkin, M., \& Thompson, A. (2011). Interpretative phenomenological analysis in mental health and psychotherapy research. In A. R. Thompson \& D. Harper (Eds.), Qualitative research methods in mental health and psychotherapy: A guide for students and practitioners (pp. 99-116). Chichester, UK: John Wiley \& Sons, Ltd.

Lent, R. W., \& Brown, S. D. (1996). Social cognitive approach to career development: An overview. The Career Development Quarterly, 44(4), 310-32 1. Available at: https://doi.org/10.1002/j.2161-0045.1996.tbo0448.x.

Lent, R. W., Brown, S. D., \& Hackett, G. (1994). Toward a unifying social cognitive theory of career and academic interest, choice, and performance. Journal of Vocational Behavior, 45(1), 79-122. Available at: https://doi.org/10.1006/jvbe.1994.1027.

Lent, R. W., Lopez, A. M., Lopez, F. G., \& Sheu, H.-B. (2008). Social cognitive career theory and the prediction of interests and choice goals in the computing disciplines. Journal of Vocational Behavior, 73(1), 52-62. Available at: https://doi.org/10.1016/j.jvb.2008.01.002.

Marks, H. M. (2000). Student engagement in instructional activity: Patterns in the elementary, middle, and high school years. American Education Research Journal, 37(1), 153-184.

Martino, W., \& Kehler, M. (2006). Male teachers and the "boy problem": An issue of recuperative masculinity politics. McGill Journal of Education, 41(2), 113-132.

Merriam, S. B. (2009). Qualitative research: A guide to design and implementation. San Francisco, CA: Jossey Bass.

Muschkin, C. G., Ladd, H. F., Dodge, K. A., \& Bai, Y. (2020). Gender differences in the impact of North Carolina's early care and education initiatives on student outcomes in elementary school. Educational Policy, 34(2), 377-407. Available at: https://doi.org/10.1177/0895904818773901.

Pangrazi, R., \& Beighle, A. (2020). Dynamic physical education for elementary school children. Champaign, IL: Human Kinetics.

Robinson, W. H., McGee, E. O., Bentley, L. C., Houston, S. L., \& Botchway, P. K. (2016). Addressing negative racial and gendered experiences that discourage academic careers in engineering. Computing in Science E Engineering, 18(2), 29-39. Available at: https://doi.org/10.1109/MCSE.2016.38.

Seidman, I. (2013). Interviewing as qualitative research: A guide for researchers in education and the social sciences (4th ed.). New York: Teachers College Press.

Sevier, B., \& Ashcraft, C. (2009). Be careful what you ask for. Men and Masculinities, 11(5), 533-557. Available at: https://doi.org/10.1177/1097184X07302290.

Shek, D., \& Wu, F. (2014). Positive youth development in junior secondary school students: Do gender and time matter? In D. Shek, R. Sun, \& C. Ma (Eds.), Chinese adolescents in Hong Kong: Family life, psychological well-being and risk behavior. Singapore: Springer, Singapore.

Skaalvik, E. M., \& Skaalvik, S. (2017). Motivated for teaching? Associations with school goal structure, teacher self-efficacy, job satisfaction and emotional exhaustion. Teaching and Teacher Education, 67, 152-160. Available at: https://doi.org/10.1016/j.tate.2017.06.006.

Skelton, C. (2003). Male primary teachers and perceptions of masculinity. Educational Review, 55(2), 195-209. Available at: https://doi.org/10.1080/0013191032000072227.

Smith, J., \& Osborn, M. (2003). Interpretative phenomenological analysis. In Qualitative Psychology: A Practical Guide to Methods. London, UK: Sage.

Statistics B of Labor. (2020). High school teachers. Retrieved from Occupational Outlook Handbook website: https:// www.bls.gov/ooh/education-training-and-library/high-school-teachers.htm.

Swanson, J., \& Gore, P. (2000). Advances in vocational psychology theory and research. In S.D. Brown \& R. W. Lent (Eds.), Handbook of counseling psychology (233-269 ed.). Hoboken, NJ: John Wiley \& Sons Inc.

Tang, K. H., \& Dos Santos, L. M. (2017). A brief discussion and application of interpretative phenomenological analysis in the field of health science and public health. International Journal of Learning and Development, 7(3), 123-132. Available at: https://doi.org/10.5296/ijld.v7i3.11494.

Thomas, D. R. (2006). A general inductive approach for analysing qualitative evaluation data. American Journal of Evaluation, $27(2), 237-246$. Available at: https://doi.org/10.1177/1098214005283748.

Weiner, L. (2012). The future of our schools: teachers unions and social justice. Chicago, IL: Haymarket Books.

Weiner, L., \& Jerome, D. (2016). Urban teaching: The essentials (3rd ed.). New York: Teachers College Press.

Yang, C.-C., Fan, C.-W., Chen, K.-M., Hsu, S.-C., \& Chien, C.-L. (2018). As a happy kindergarten teacher: The mediating effect of happiness between role stress and turnover intention. The Asia-Pacific Education Researcher, 27(6), 431-440. Available at: https://doi.org/10.1007/s40299-018-0403-4.

Yeung, A. S. (2011). Student self-concept and effort: gender and grade differences. Educational Psychology, 6(31), 749-772. Available at: https://doi.org/10.1080/01443410.2011.608487.

Yu, X., Wang, P., Zhai, X., Dai, H., \& Yang, Q. (2015). The effect of work stress on job burnout among teachers: The mediating role of selfefficacy. Social Indicators Research, 122(3), 701-708. Available at: https://doi.org/10.1007/s1 1205-014-0716-5. 